\title{
Effect of insulin on GLUT-4 mRNA and protein concentrations in skeletal muscle of patients with NIDDM and their first-degree relatives
}

\author{
C. Schalin-Jäntti ${ }^{2}$, H. Yki-Järvinen ${ }^{1}$, L. Koranyi ${ }^{4}$, R. Bourey ${ }^{5}$, J. Lindström ${ }^{1}$, P. Nikula-Ijäs ${ }^{3}$, \\ A. Franssila-Kallunki ${ }^{2}$, L.C. Groop ${ }^{6}$ \\ ${ }^{1}$ Second Department of Medicine, Helsinki University, Helsinki, Finland \\ ${ }^{2}$ Fourth Department of Medicine, Helsinki University, Helsinki, Finland \\ ${ }^{3}$ Department of Biochemistry, Helsinki University, Helsinki, Finland \\ ${ }^{4}$ Department of Metabolism, Hungarian Heart Center, Balatonfüred, Hungary \\ ${ }^{5}$ Metabolism Division, Department of Internal Medicine, Washington University School of Medicine, St. Louis, Missouri, USA \\ ${ }^{6}$ Department of Endocrinology, University of Lund, Malmö General Hospital, Malmö, Sweden
}

\begin{abstract}
Summary We examined whether insulin resistance, i.e. impaired insulin stimulated glucose uptake in NIDDM patients and their first-degree relatives is associated with alterations in the effect of insulin on the expression of the GLUT-4 gene in skeletal muscle in vivo. Levels of GLUT-4 mRNA and protein were measured in muscle biopsies taken before and after a euglycaemic insulin clamp from 14 NIDDM patients, 13 of their first-degree relatives and 17 control subjects. Insulin stimulated glucose uptake was decreased in the diabetic subjects $\left(19.8 \pm 3.0 \mu \mathrm{mol} \cdot \mathrm{kg} \mathrm{LBM} \mathrm{LB}^{-1} \cdot \mathrm{min}^{-1}\right.$, both $p<0.001)$ compared with control subjects $\left(44.1 \pm 2.5 \mu \mathrm{mol} \cdot \mathrm{kg} \quad \mathrm{LBM}^{-1} \cdot \mathrm{min}^{-1}\right) \quad$ and relatives $\left(39.9 \pm 3.3 \mu \mathrm{mol} \cdot \mathrm{kg} \quad \mathrm{LBM}^{-1} \cdot \mathrm{min}^{-1}\right)$. Basal GLUT-4 mRNA levels were significantly higher in diabetic subjects and relatives compared to control subjects $(99 \pm 8$ and $108 \pm 9 \mathrm{pg} / \mu \mathrm{g}$ RNA vs $68 \pm 5 \mathrm{pg} / \mu \mathrm{g}$ RNA; both $p<0.01$ ). Insulin increased GLUT-4 mRNA levels in all control subjects (from $68 \pm 5$ to $92 \pm 6 \mathrm{pg} / \mu \mathrm{g}$ RNA; $p<0.0001$ ), but not in the diabetic patients (from $99 \pm 8$ to $90 \pm 8 \mathrm{pg} / \mu \mathrm{g}$ RNA, NS), or their relatives (from $94 \pm 9$ to $101 \pm 11 \mathrm{pg} / \mu \mathrm{g}$ RNA, NS). In the relatives, individual basal GLUT-4 mRNA concentrations varied between 55 and $137 \mathrm{pg} / \mu \mathrm{g}$ RNA. Insulin-resistant
\end{abstract}

$(n=6$, mean glucose uptake rate $=30.6 \pm 3.4 \mu \mathrm{mol} \cdot \mathrm{kg}$ $\left.\mathrm{LBM}^{-1} \cdot \mathrm{min}^{-1}\right)$ but not insulin-sensitive relatives $(n=7$, mean glucose uptake rate $=47.4 \pm 3.2 \mu \mathrm{mol} \cdot \mathrm{kg} \mathrm{LBM}^{-1}$ - min $^{-1}$ ) had higher basal GLUT-4 mRNA concentrations compared to control subjects ( $108 \pm 9$ vs $68 \pm 5$ $\mathrm{pg} / \mu \mathrm{g}$ RNA, $p<0.01)$. GLUT-4 protein content in muscle did not differ between the groups in the basal state and remained unchanged in all groups after insulin infusion. Neither insulin-stimulated GLUT-4 mRNA nor protein concentrations correlated with insulin-stimulated glucose uptake in any of the groups studied. We conclude, that impaired glucose uptake in NIDDM is not related to insulin-stimulated GLUT-4 mRNA or protein concentrations. Acute stimulation of GLUT-4 mRNA by insulin is altered in skeletal muscle of NIDDM patients and their first-degree relatives. This might be a consequence of chronic hyperinsulinaemia elevating basal GLUT- 4 mRNA concentrations rather than the cause of insulin resistance. [Diabetologia (1994) 37: 401-407]

Key words Insulin resistance, glucose transport, muscle, insulin, GLUT-4, NIDDM.
Received: 2 July 1993

and in revised form: 4 November 1993

Corresponding author: Dr. C.Schalin-Jäntti, Fourth Department of Medicine, Helsinki University Hospital, Unioninkatu 38, SF-00 170 Helsinki, Finland

Abbreviations: NIDDM, Non-insulin dependent diabetes mellitus; GLUT-4, glucose transporter 4; LBM, lean body mass; IDDM, insulin-dependent diabetes mellitus
Non-insulin-dependent diabetes mellitus (NIDDM) has a strong genetic component as evidenced by the high concordance rate in monozygous twins [1]. One major feature of the disease is insulin resistance, i. e. reduced glucose disposal in skeletal muscle $[2,3]$. It has been suggested that insulin resistance per se is inherited, because it can be demonstrated in nondiabetic, first-degree relatives of NIDDM patients [46]. The exact molecular mechanisms underlying insulin resistance in NIDDM are unclear. One possibility is defective expression of the gene encoding for GLUT-4, 
which facilitates insulin-stimulated glucose transport in skeletal muscle [7]. Decreased GLUT-4 mRNA levels have been reported in rats with streptozotocin-induced diabetes $[8,9]$. Although decreased glucose transporter protein concentrations have been reported in insulinresistant patients [10], most human data would argue against altered expression of the GLUT-4 gene in NIDDM [11-14]. However, in these studies GLUT-4 mRNA and protein concentrations were measured only in the basal state after an overnight fast. Since GLUT-4 is expressed only in insulin sensitive tissues, altered expression in the insulin-stimulated state could contribute to impaired insulin-stimulated glucose uptake in NIDDM. If only NIDDM patients are studied, it is difficult to distinguish between inherited and secondary causes of insulin resistance. To circumvent this problem we included a group of normoglycaemic, firstdegree relatives of NIDDM patients in the study. It has been estimated, that $43 \%$ of first-degree relatives of patients with NIDDM ultimately develop the disease [15]. Thus, to study whether impaired expression of the insulin regulatable glucose transporter GLUT-4 contributes to impaired insulin-stimulated glucose uptake in NIDDM, we measured the effect of insulin on glucose uptake, GLUT-4 mRNA and protein concentrations in skeletal muscle in NIDDM patients, their firstdegree relatives and healthy control subjects.

\section{Subjects, materials and methods}

\section{Subjects}

Fourteen patients with NIDDM, 13 first-degree relatives of patients with NIDDM and 17 control subjects with no family history of diabetes participated in the study (Table 1). Prior to the study, the control subjects and relatives participated in an oral $(75 \mathrm{~g})$ glucose tolerance test. All control subjects and seven of the relatives had normal glucose tolerance, while six of the relatives had impaired glucose tolerance according to World Health Organization criteria. Two of the relatives with impaired glucose tolerance were classified as insulin resistant according to glucose uptake rates during the insulin clamp, while the other four were insulin sensitive. All subjects were of European descent, none of them had clinical evidence of cardiac, hepatic or renal disease or endocrine disease other than diabetes. Informed consent was obtained from all subjects, and the study protocol was approved by the ethical committee of the Helsinki University Hospital.

\section{Protocol}

Insulin sensitivity was measured by a euglycaemic, hyperinsulinaemic clamp in combination with indirect calorimetry. After three baseline samples had been taken for measurement of glucose and insulin concentrations, a primed constant infusion of short-acting human insulin (Actrapid; Novo-Nordisk, Copenhagen, Denmark) was administered at a rate of $45 \mathrm{mU} \cdot \mathrm{m}^{-2}$. $\mathrm{min}^{-1}\left(340 \mathrm{pmol} \cdot \mathrm{m}^{-2} \cdot \mathrm{min}^{-1}\right)$ for $3 \mathrm{~h}$. The plasma glucose concentration was determined at 5 -min intervals, and $20 \%$ glucose was infused to maintain a constant plasma glucose concentration. At
Table 1. Clinical characteristics of subjects

\begin{tabular}{lccc}
\hline & $\begin{array}{l}\text { Control } \\
\text { subjects }\end{array}$ & $\begin{array}{l}\text { Relatives } \\
\text { of NIDDM } \\
\text { patients }\end{array}$ & $\begin{array}{l}\text { NIDDM } \\
\text { patients }\end{array}$ \\
\hline $\begin{array}{l}\text { Sex } \\
\text { (female/male) }\end{array}$ & $17(2 / 15)$ & $13(6 / 7)$ & $14(4 / 10)$ \\
$\begin{array}{l}\text { Age } \\
\text { (years) }\end{array}$ & $53 \pm 3$ & $49 \pm 3$ & $58 \pm 2^{\mathrm{a}}$ \\
$\begin{array}{l}\text { BMI } \\
\left.\text { (kg/m }{ }^{2}\right)\end{array}$ & $26.5 \pm 0.6$ & $27.8 \pm 0.8$ & $28.2 \pm 1.2$ \\
$\begin{array}{l}\text { Fasting plasma } \\
\text { glucose (mmol/1) }\end{array}$ & $5.3 \pm 0.1$ & $5.4 \pm 0.1$ & $10.9 \pm 0.9^{* * * *}$ \\
$\begin{array}{l}\text { HbA } \\
\text { (\%) }\end{array}$ & $5.1 \pm 0.1$ & $5.2 \pm 0.1$ & $8.5 \pm 0.4^{* * *}$ \\
$\begin{array}{l}\text { Fasting insulin } \\
\text { (pmol/1) }\end{array}$ & $48.7 \pm 5.8$ & $67.7 \pm 10.6$ & $95.2 \pm 16.9^{* * *}$ \\
$\begin{array}{l}\text { Cholesterol } \\
\text { (mmol/l) }\end{array}$ & $5.5 \pm 0.2$ & $5.6 \pm 0.3$ & $5.6 \pm 0.4$ \\
$\begin{array}{l}\text { Triglycerides } \\
\text { (mmol/1) }\end{array}$ & $1.5 \pm 0.2$ & $1.5 \pm 0.2$ & $2.2 \pm 0.3^{\mathrm{a}}$ \\
\hline
\end{tabular}

$* p<0.05$ vs relatives; $* * p<0.01$ vs control subjects; $* * * p<0.001$ vs control subjects and relatives

a constant plasma glucose concentration, the amount of glucose required to maintain euglycaemia equals the rate for whole body glucose metabolism. The steady-state plasma glucose and serum insulin concentrations achieved during the last $60 \mathrm{~min}$ of the clamp did not differ significantly between NIDDM patients, relatives and control subjects $(6.1 \pm 0.2,5.4 \pm 0.1$ and $5.4 \pm 0.04 \mathrm{mmol} / \mathrm{l}$ and $596 \pm 54,583 \pm 42$ and $580 \pm 49 \mathrm{pmol} / \mathrm{l}$, respectively). The corresponding coefficients of variation were 4.9, 5.4 and $5.2 \%$ for glucose and 7, 7 and $6 \%$ for insulin, respectively.

Indirect calorimetry was employed during $60 \mathrm{~min}$ in the basal state and during the last $60 \mathrm{~min}$ of the insulin clamp to estimate glucose and lipid oxidation rates [16]. A computerized, open-circuit system was used to measure gas exchange through a transparent plastic canopy (Deltatrac; Datex, Helsinki, Finland). Flow was measured by the air-dilution method, the carbon dioxide concentration by an infrared detector, and the oxygen concentration by a differential paramagnetic sensor. The monitor has a precision of $2.5 \%$ for oxygen consumption and of $1.0 \%$ for carbon dioxide production. LBM was determined with bioelectrical impedance [17].

Total-body glucose metabolism equals the mean rate of glucose infusion during the last $60 \mathrm{~min}$ of the clamp. Non-oxidative glucose metabolism i.e. glucose storage in skeletal muscle, was calculated as the difference between total-body glucose metabolism and glucose oxidation as determined by indirect calorimetry. Net glucose oxidation rates were calculated from indirect calorimetry measurements according to Ferrannini [16].

\section{Muscle biopsies}

A percutaneous muscle biopsy (20-40 $\mathrm{mg}$ ) was taken in the basal state before starting the insulin infusion and at the end of the insulin clamp from the vastus lateralis muscle under local anaesthesia ( $1 \%$ lidocaine) using a Bergström needle. The muscle specimens were immediately placed into liquid nitrogen and kept frozen at $-70^{\circ} \mathrm{C}$ until analysed. 
Table 2. Characteristics of muscle biopsies

\begin{tabular}{|c|c|c|c|}
\hline & $\begin{array}{l}\text { Control } \\
\text { subjects }\end{array}$ & $\begin{array}{l}\text { Relatives of } \\
\text { NIDDM patients }\end{array}$ & $\begin{array}{l}\text { NIDDM } \\
\text { patients }\end{array}$ \\
\hline \multicolumn{4}{|l|}{ RNA/mg tissue ( $\mu g / m g)$} \\
\hline Basal state & $0.924 \pm 0.132$ & $0.869 \pm 0.195$ & $0.961 \pm 0.218$ \\
\hline Insulin-stimulated state & $0.946 \pm 0.092$ & $1.136 \pm 0.247$ & $0.952 \pm 0.214$ \\
\hline \multicolumn{4}{|l|}{ DNA/mg tissue $(\mu g / m g)$} \\
\hline Basal state & $0.838 \pm 0.044$ & $0.708 \pm 0.060$ & $0.866 \pm 0.098$ \\
\hline Insulin-stimulated state & $0.786 \pm 0.051$ & $0.694 \pm 0.051$ & $0.868 \pm 0.068$ \\
\hline \multicolumn{4}{|l|}{ Protein content $(\%)$} \\
\hline Basal state & $11.6 \pm 0.7$ & $12.9 \pm 1.1$ & $11.8 \pm 0.8$ \\
\hline Insulin-stimulated state & $10.8 \pm 0.6$ & $11.5 \pm 0.6$ & $11.4 \pm 1.0$ \\
\hline
\end{tabular}

\section{Assays}

Plasma glucose concentrations were measured by the glucose oxidase method using a Beckman glucose analyzer II (Beckman Instruments, Fullerton, Calif., USA). Blood glycohaemoglobin concentrations were measured by HPLC (reference range 4$6 \%$ ). Serum free insulin concentrations were measured by a double-antibody RIA (Pharmacia, Uppsala, Sweden).

\section{Quantitation of GLUT-4 $m R N A$}

Total tissue RNA was extracted using a modified guanidine thiocyanate (GuSCN) water saturated phenol extraction method [18]. Samples were homogenized in $4 \mathrm{~mol} / \mathrm{l} \mathrm{GuSCN}$ containing octylphenolethylenoxid detergent (non-ident P-40; Sigma Chemical Co., St. Louis, Mo., USA) and multiple phenol/chloroform/isoamylalcohol extractions were applied. After determining the absorbance at 260 and $280 \mathrm{~nm}$, aliquots of RNA were run on minigels to verify the integrity of the RNA preparation. The $\mathrm{A}_{260} / 280$ ratio and the $28 \mathrm{~S} / 18 \mathrm{~S}$ RNA ratio (determined by densitometric analyses on ethidium bromide stained minigels) were greater than 2 for all samples. Quantitation of GLUT-4 mRNA was performed by dot blot analysis utilizing a human GLUT-4 cDNA probe. Human GLUT-4 cDNA was isolated from a jejunal cDNA library [19] using rat GLUT-4 as the probe [20]. Sequence analysis indicated that the 1.7 kilobase human cDNA insert was identical to the $\lambda$ HJHT-3 clone previously described [21]. This clone contains a 260 base pair intron at the 3 ' end. The cDNA was subcloned into a Bluescript SK + plasmid (Stratagene, La Jolla, Calif., USA). Transcription of synthetic mRNA standard and ${ }^{32} \mathrm{P}$-labelled cRNA with T3 or T7 RNA polymerase was performed according to the manufacturer's instructions. After hybridization of this probe to human muscle RNA, a single 3.3 kilobase band was observed on the Northern blots. There were no differences in the size of this band if muscle samples were taken before or after insulin infusion. Aliquots of sample total RNA $(0.5-10 \mu \mathrm{g})$, of transfer RNA $(10 \mu \mathrm{g})$ and human liver RNA $(10 \mu \mathrm{g})$ as controls and dilutions of synthetic mRNA (0.5$1000 \mathrm{pg}$ ) were used as standards and dissolved in $15 \%$ formaldehyde $/ 10 \times$ standard saline citrate (SSC) and blotted onto Nytran (Schleicher and Schuell Inc., Keene, NH, USA) membranes. The membranes were hybridized for $16-18 \mathrm{~h}$ at $60^{\circ} \mathrm{C}$ in a $50 \%$ formamide, $5 \times \mathrm{SSPE}(0.75 \mathrm{~mol} / 1 \mathrm{NaCl}, 5 \mathrm{mmol} / 1 \mathrm{EDTA}$, $50 \mathrm{mmol} / 1 \quad \mathrm{NaH}_{2} \mathrm{PO}_{4}, \mathrm{pH} 7.4$ ), $5 \times$ Denhardts', $0.1 \%$ SDS, $200 \mu \mathrm{g} / \mathrm{ml}$ salmon sperm DNA and then washed at $65^{\circ} \mathrm{C}$ in $0.1 \times$ SSC, $0.1 \%$ SDS, according to the recommendations of the vendor. Blots were exposed to Kodak XAR 5 film at $-70^{\circ} \mathrm{C}$ using intensifying screens (Cronex Lightening Plus; E. I. Dupont de Nemours Co., Wilmington, Del., USA). The amount of mRNA present in each sample determined in duplicate, was measured by densitometric analysis, comparing the intensity of the sample dot with standard dots. Autoradiographs were developed for various periods of time so that intensity of the unknown samples was within linear range of standards. The coefficient of variation was $8.7 \%$. The DNA concentrations in homogenized tissue samples were determined by fluorometer using the Hoechst 33258 dye, with a $9.2 \%$ coefficient of variation.

\section{Immunoblotting}

Muscle samples were homogenized with a polytron homogenizer (Brinkman, Westbury, NY, USA) on ice at high speed for $45 \mathrm{~s}$ in HES buffer $(20 \mathrm{mmol} / \mathrm{l}$ Hepes, $1 \mathrm{mmol} / \mathrm{l}$ EDTA, $250 \mathrm{mmol} / 1$ sucrose, $\mathrm{pH} 7.4,1: 40$ weight/volume). The protein concentration was determined by a method based on a bicinchoninic acid reaction (Pierce, Rockford, Ill., USA), $50 \mu \mathrm{g}$ samples of protein were subjected to SDS-PAGE by loading six paired and two standard samples per gel (Bio-Rad Mini Protean II, Richmond, Calif., USA). Protein was electrophoretically transferred (Polyblot; ABN, Hayward, Calif., USA) to nitrocellulose paper. Nitrocellulose sheets were incubated with phosphate-buffered saline ( $\mathrm{pH} \mathrm{7.4)} \mathrm{containing} 50 \mathrm{mg} / \mathrm{ml}$ of powdered milk (Valio, Helsinki, Finland) for $60 \mathrm{~min}$ at $22^{\circ} \mathrm{C}$ and thereafter with a polyclonal antibody specific for the 25 amino acid GLUT-4 carboxy-terminus peptide (F349). After washing, blots were incubated with ${ }^{125}$ I-labelled donkey anti-rabbit IgG (Amersham Inc., Amersham, Bucks., UK). Quantitation was performed by excising labelled bands and counting in a gamma counter (Wallac, Turku, Finland). Equal areas away from the band of interest were excised and analysed to establish background. Inter- and intra-gel assay coefficients of variation were 25 and $13 \%$, respectively.

\section{Statistical analysis}

All data are expressed as mean \pm SEM. All statistical analyses were performed using a BMDP statistical package (Biomedical Data Processing, 1988, Los Angeles, Calif., USA). Differences between group means were tested by Mann-Whitney rank sum test and corrected for multiple comparisions by the Bonferoni method. Correlations were tested by linear regression analysis. 
Table 3. Insulin stimulated glucose metabolism $(\mu \mathrm{mol} \cdot \mathrm{kg}$ $\mathrm{LBM}^{-1} \cdot \min ^{-1}$ )

\begin{tabular}{llll}
\hline & $\begin{array}{l}\text { Control } \\
\text { subjects }\end{array}$ & $\begin{array}{l}\text { Relatives of } \\
\text { NIDDM patients }\end{array}$ & $\begin{array}{l}\text { NIDDM } \\
\text { patients }\end{array}$ \\
\hline$n$ & 17 & 13 & 14 \\
$\begin{array}{l}\text { Glucose } \\
\text { disposal }\end{array}$ & $44.1 \pm 2.5$ & $39.6 \pm 3.3$ & $19.8 \pm 3.0^{\mathrm{a}}$ \\
$\begin{array}{l}\text { Glucose } \\
\text { oxidation }\end{array}$ & $17.3 \pm 0.8$ & $19.2 \pm 1.1$ & $10.2 \pm 1.3^{\mathrm{a}}$ \\
$\begin{array}{l}\text { Glucose } \\
\text { storage }\end{array}$ & $26.8 \pm 2.1$ & $20.4 \pm 3.4$ & $9.6 \pm 2.4^{\mathrm{b}}$ \\
\hline
\end{tabular}

${ }^{\mathrm{a}} p<0.001 ;{ }^{\mathrm{b}} p<0.001-0.02$ vs control subjects and relatives

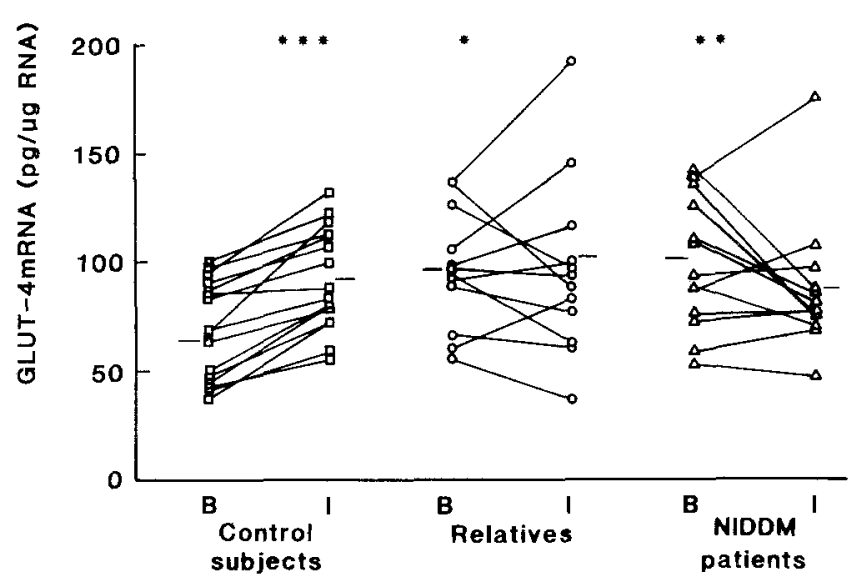

Fig. 1. The GLUT-4 mRNA concentrations in vastus lateralis muscle of control subjects $(\square, n=17)$, relatives of patients with NIDDM $(O, n=13)$ and patients with NIDDM $(\Delta, n=14)$ in the basal (B) and insulin-stimulated state (I). ${ }^{*} p<0.05$; ** $p<0.01$ vs control subjects; $* * * *<<0.0001$ vs basal concentration

\section{Results}

Clinical characteristics of the subjects are given in Table 1. The DNA, RNA and protein contents of muscle biopsies (vastus lateralis muscle) were similar in the three groups studied (Table 2).

\section{In vivo insulin sensitivity}

Insulin stimulated glucose uptake was reduced by $55 \%$ in NIDDM patients compared to control subjects (Table 3). The impairment in glucose metabolism in diabetic subjects was due to both impaired storage and oxidation of glucose $(p<0.001$ vs control subjects and relatives). Mean glucose uptake rates in the relatives did not differ significantly from that in control subjects (Table 3), but the individual values were varied as expected. Therefore, relatives were divided intoinsulinsensitive and insulin-resistant subjects based on the median glucose uptake rate. The mean glucose uptake rate in insulin-resistant relatives $(n=6,30.6 \pm$ $3.4 \mu \mathrm{mol} \cdot \mathrm{kg} \mathrm{LBM}^{-1} \cdot \mathrm{min}^{-1}$, range $=18.7-35.8 \mu \mathrm{mol} \cdot \mathrm{kg}$
$\mathrm{LBM}^{-1} \cdot \mathrm{min}^{-1}$ ) was decreased compared with insulinsensitive relatives $\left(n=7,47.4 \pm 3.2 \mu \mathrm{mol} \cdot \mathrm{kg} \mathrm{LBM}^{-1}\right.$ $\cdot \mathrm{min}^{-1}$, range $\left.=39.1-63.8 \mu \mathrm{mol} \cdot \mathrm{kg} \mathrm{LBM}{ }^{-1} \cdot \mathrm{min}^{-1}\right)$ and control subjects $(p<0.01-0.03)$. The decrease in glucose disposal in the insulin-resistant relatives was due to impaired glucose storage $(10.7 \pm 3.2 \mathrm{vs} 26.8 \pm 2.2 \mu \mathrm{mol} \cdot \mathrm{kg}$ $\mathrm{LBM}^{-1} \cdot \mathrm{min}^{-1}, p<0.01$ vs control subjects), while insulin stimulated glucose oxidation was normal $(19.9 \pm 0.8$ vs $\left.17.3 \pm 0.8 \mu \mathrm{mol} \cdot \mathrm{kg} \mathrm{LBM}{ }^{-1} \cdot \mathrm{min}^{-1}\right)$.

Both diabetic subjects $(p<0.001)$ and insulin-resistant relatives $(87.4 \pm 19.7 \mathrm{pmol} / 1 ; p=0.055)$ had higher fasting insulin concentrations compared to control subjects (Table 1). The fasting insulin concentrations in the insulin-sensitive relatives $(50.8 \pm 5.7 \mathrm{pmol} / 1)$ did not differ from control subjects, but were lower than in the NIDDM patients $(p<0.03)$.

\section{GLUT-4 mRNA and protein concentrations}

Mean basal GLUT-4 mRNA levels expressed per $\mu \mathrm{g}$ of total RNA were significantly higher in the diabetic subjects and the relatives compared to control subjects ( $p<0.01$ and $p<0.05$, respectively) (Fig. 1). As shown in Figure 1, individual basal GLUT-4 mRNA values in the relatives varied between 55 and $137 \mathrm{pg} / \mu \mathrm{g}$ RNA. The increase in basal GLUT-4 mRNA in the relatives was due to high basal concentrations in the insulin-resistant subjects $(108 \pm 9 \mathrm{pg} / \mu \mathrm{g}$ RNA; $p<0.01$ vs control subjects), while the concentrations in the insulin-sensitive relatives ( $80 \pm 14 \mathrm{pg} / \mu \mathrm{g}$ RNA) did not differ from those in the control subjects. Diabetic subjects $(n=11)$ and relatives $(n=9)$ also tended to have higher basal GLUT-4 mRNA levels expressed per $\mu \mathrm{g}$ of total DNA compared to control subjects ( $89 \pm 17$ and $114 \pm 25$ vs $73 \pm 10 \mathrm{pg} / \mu \mathrm{g}$ DNA, respectively).

Insulin caused a significant increase in GLUT-4 mRNA concentrations in all control subjects, expressed both per total RNA (Fig. 1) and DNA (from $73 \pm 10$ to $124 \pm 22 \mathrm{pg} / \mu \mathrm{g}$ DNA), both $p<0.0001$. This effect was lacking in the diabetic subjects, in whom mean GLUT-4 mRNA levels were unchanged after insulin infusion both when expressed per RNA (Fig. 1) and DNA ( $n=11$; from $89 \pm 17$ to $94 \pm 25 \mathrm{pg} / \mu \mathrm{g}$ RNA, NS). In the relatives, insulin neither changed mean GLUT-4 mRNA levels expressed per RNA (Fig. 1) nor expressed per DNA ( $n=9$; from $114 \pm 25$ to $127 \pm 28$ $\mathrm{pg} / \mu \mathrm{g}$ DNA, $p=\mathrm{NS}$ ). This was primarily due to lack of insulin effect in the insulin-resistant subjects (from $108 \pm 9$ to $111 \pm 17 \mathrm{pg} / \mu \mathrm{g}$ RNA), while in insulin-sensitive relatives a slight (from $80 \pm 14$ to $93 \pm 15 \mathrm{pg} / \mu \mathrm{g}$ RNA) increase in GLUT-4 mRNA concentrations was observed. GLUT-4 mRNA levels after insulin infusion did not correlate with insulin-stimulated glucose uptake in control subjects, relatives or diabetic subjects ( $r=0.06, r=-0.23$ and $r=-0.07$, all NS, respectively).

Basal GLUT-4 protein concentrations did not differ between control subjects, relatives or diabetic patients 


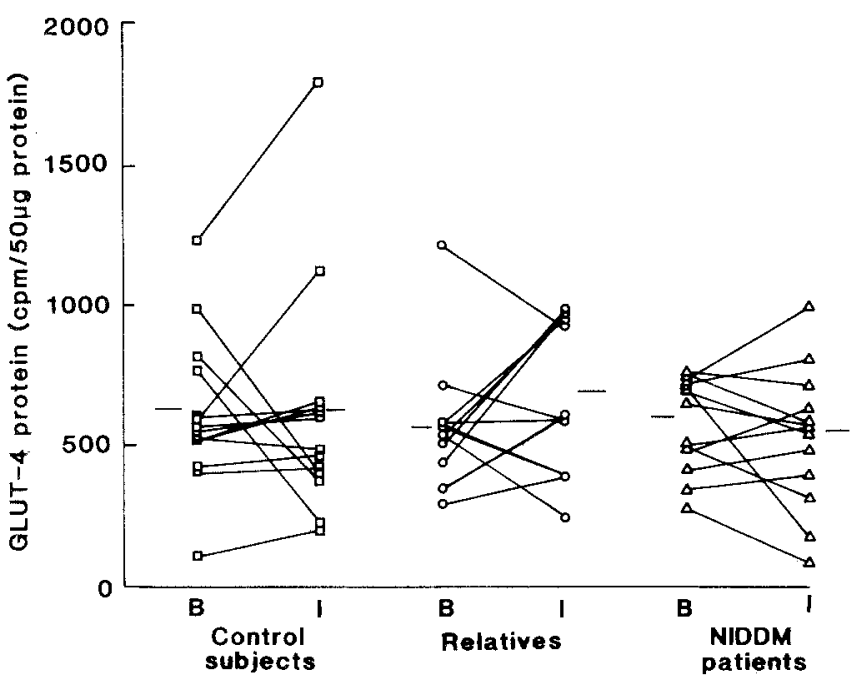

Fig. 2. The GLUT-4 protein concentrations in vastus lateralis muscle from control subjects ( $\square, n=15$ ), relatives of patients with $\operatorname{NIDDM}(O, n=12)$ and patients with $\operatorname{NIDDM}(\Delta, n=13)$ in the basal (B) and insulin-stimulated state (I)

expressed either per mg of protein (Fig. 2) or per DNA (data not shown). Insulin did not induce significant changes in GLUT-4 protein concentrations expressed either per protein (Fig. 2) or per DNA in any of the groups studied. GLUT-4 protein levels measured at the end of the insulin infusion did not correlate with insulin-stimulated glucose uptake in any of the groups.

\section{Discussion}

In the present study, we found that insulin significantly increases GLUT-4 mRNA concentrations in skeletal muscle of healthy subjects. While this was a consistent finding in all control subjects, the response in NIDDM patients and their relatives was heterogenous, with most diabetic subjects and some of the relatives having high basal GLUT-4 mRNA concentrations, which were not further stimulated by acute hyperinsulinaemia. The findings are in accordance with a recent study by Andersen et al [22], showing significant increase in GLUT4 mRNA concentrations after insulin in healthy subjects but not in subjects with NIDDM. About $40 \%$ of the relatives are estimated to develop NIDDM [15] and among these individuals insulin resistance is prevalent [4-6].

NIDDM patients differ from control subjects with respect to higher basal glucose and insulin concentrations. It is unlikely that the increase in basal GLUT-4 mRNA concentrations in the diabetic patients was the consequence of hyperglycaemia, as normoglycaemic insulin-resistant relatives also had elevated basal GLUT-4 mRNA concentrations. The increased basal GLUT-4 mRNA concentrations in the diabetic patients confirm our previous findings [13]. However, the present study shows that first-degree relatives of
NIDDM patients also have increased basal GLUT-4 mRNA concentrations, provided they are insulin resistant and not insulin sensitive. This is in accordance with the finding of increased expression of protein phosphatase 1 and insulin receptor substrate 1 in the basal state in skeletal muscle of insulin-resistant subjects [23, 24]. In fact, a tendency towards high basal GLUT-4 mRNA levels in NIDDM patients was also shown by Garvey et al. [14].

As diabetic patients and insulin-resistant relatives had elevated fasting insulin levels compared to control subjects, one could argue that chronic hyperinsulinaemia in these subjects is able to stimulate basal GLUT-4 mRNA levels essentially to the same extent as acute hyperinsulinaemia in the control subjects. This hypothesis is supported by the lack of difference in basal GLUT-4 mRNA concentrations between hyperglycaemic IDDM patients and normal subjects who had similar insulin concentrations [25]. In the present study, the absence of a stimulatory effect of acute hyperinsulinaemia on GLUT-4 mRNA concentrations in diabetic patients and insulin-resistant relatives could therefore be due to the fact that basal GLUT- 4 mRNA concentrations already were stimulated by chronic hyperinsulinaemia. However, there are several exceptions from this rule, especially among the relatives. The present finding of an altered response of GLUT-4 mRNA concentrations to the stimulatory effect of acute hyperinsulinaemia both in NIDDM patients and in their first-degree relatives might suggest altered transcriptional regulation of the GLUT-4 gene by insulin in NIDDM. Alternatively, the finding of decreased GLUT-4 mRNA concentrations after insulin stimulation could imply accelerated degradation of GLUT-4 mRNA in insulin-resistant individuals. Interestingly, insulin also fails to stimulate GLUT-4 mRNA concentrations in IDDM patients, who have an acquired form of insulin resistance [25]. Because of the difference in basal GLUT-4 mRNA concentrations between the groups in the present study, it cannot be determined whether the lack of response of GLUT-4 mRNA to insulin represents a true defect in insulin action or only reflects high basal GLUT-4 mRNA which has been stimulated by basal hyperinsulinaemia.

It has also been shown, that insulin resistance is associated with alterations in insulin-stimulated gene expression of a number of genes in human skeletal muscle [26]. It is therefore possible, that the impaired insulinstimulated GLUT-4 mRNA concentrations measured in our diabetic subjects and their insulin-resistant relatives is the consequence rather than the cause of insulin resistance.

Basal GLUT-4 protein concentrations did not differ between control subjects, relatives and NIDDM patients, confirming the results of several previous studies [11-14]. Could the absence of a stimulatory effect of acute hyperinsulinaemia on GLUT-4 mRNA concentrations impair glucose uptake in NIDDM? The lack of 
stimulation of GLUT-4 mRNA concentrations by insulin was not, however, followed by a concomitant reduction in GLUT-4 transporter protein concentrations. The discrepancy between GLUT-4 mRNA and protein concentrations after insulin stimulation has been described previously in healthy subjects $[22,25]$. Handberg et al. [27] reported a 19\% decrease in GLUT-4 protein content after $3 \mathrm{~h}$ of insulin infusion in a study of healthy subjects, but did not measure GLUT-4 mRNA concentrations. In the present study, insulin did not induce any significant changes in GLUT-4 protein content in control subjects, relatives or in NIDDM patients. In support of this, Andersen et al. [22] could not demonstrate any effect of a 4-h insulin infusion on GLUT-4 protein content in patients with NIDDM. Common to the present and previous studies [22, 27], no correlations between insulin-stimulated GLUT-4 mRNA or protein concentrations and insulin-stimulated glucose disposal was observed in any of the groups studied. This suggests, that there is no causal relationship between insulin-stimulated GLUT-4 mRNA or protein concentrations and insulin-stimulated glucose uptake rates.

From studies in rats it is known that insulin sensitivity is dependent on muscle fibre-type composition [28]. Alterations in fibre-type composition could therefore explain at least part of the decreased insulin-stimulated muscle glucose uptake in insulin-resistant states such as NIDDM. However, Garvey et al. [14] found no differences in muscle fibre-type composition in biopsies taken from the same site as in our study (vastus lateralis muscle) in patients with NIDDM or impaired glucose tolerance as compared to lean or obese non-diabetic control subjects.

Although the actual amount of muscle GLUT-4 transporters seems to be unaffected in NIDDM, it is still possible that other aspects of the GLUT-4 transporter are more important for insulin-stimulated glucose uptake. In rats, the acute effect of insulin has been shown to involve redistribution of preformed GLUT-4 transporters to the plasma membrane without affecting total transporter content [29-31]. Insulin might also increase the intrinsic activity of the glucose transporter $[29,32]$. Further studies are required to reveal whether alterations in subcellular distribution or glucose transporter function, such as impaired translocation, fusion with the plasma membrane or activation contribute to insulin resistance in NIDDM [33]. Altogether, 1) there is no causal relationship between insulin-stimulated GLUT-4 mRNA or protein concentrations and insulinstimulated glucose uptake either in healthy subjects or in NIDDM patients or their relatives, 2) NIDDM patients and their insulin-resistant first-degree relatives are characterized by high basal GLUT- 4 mRNA levels, which may be induced by chronic hyperinsulinaemia. The acute stimulatory effect of insulin on GLUT-4 mRNA concentrations is altered in NIDDM and in insulin-resistant, first-degree relatives of patients with
NIDDM. This may be the consequence rather than the cause of insulin resistance in these subjects.

Acknowledgements. We thank Ms. M.Parkkonen and Ms. E. Kostamo for their excellent technical assistance. This study was supported by grants from the Sigrid Jusélius Foundation, the Perklén Foundation, the Nordisk Insulin Foundation, Finska Läkaresällskapet and Duodecim.

\section{References}

1. Barnett AH, Eff C, Leslie RDG, Pyke DA (1981) Diabetes in identical twins: a study of 200 pairs. Diabetologia 20: 87-93

2. Golay A, DeFronzo RA, Ferrannini E et al. (1988) Oxidative and non-oxidative glucose metabolism in non-obese type 2 (non-insulin dependent) diabetic patients. Diabetologia 31: 585-591

3. Groop LC, Bonadonna RC, DelPrato S et al. (1989) Glucose and free fatty acid metabolism in non-insulin dependent diabetes mellitus. Evidence for multiple sites of insulin resistance. J Clin Invest 84: 205-213

4. Eriksson J, Franssila-Kallunki A, Ekstrand A et al. (1989) Early metabolic defects in persons at increased risk for noninsulin-dependent diabetes mellitus. N Engl J Med 321: $337-$ 343

5. Gulli G, HaffnerS, Ferrannini E, DeFronzo RA (1990) What is inherited in NIDDM? Diabetes 39 [Suppl 1]: 116 A (Abstract)

6. Lillioja S, Mott DM, Zawadzki JK et al. (1987) In vivo insulin action is familial characteristic in nondiabetic Pima Indians. Diabetes 36: 1329-1335

7. Bell GI, Murray JC, Nakamura Y et al. (1989) Polymorphic human insulin-responsive glucose transporter gene on chromosome 17p13. Diabetes 38: 1072-1075

8. Berger J, Biswas C, Vicario P, Strout HV, Saperstein R, Pilch $\mathrm{P}$ (1989) Decreased expression of the insulin-responsive glucose transporter in diabetes and fasting. Nature 340: 70-72

9. Garvey WT, Huecksteadt TP, Birnbaum MJ (1989) Pretranslational suppression of an insulin responsive glucose transporter in rats with diabetes mellitus. Science $245: 60-63$

10. Dohm GL, Elton CW, Friedman JE et al. (1991) Decreased expression of glucose transporter in muscle from insulin-resistant patients. Am J Physiol 260: E459-E463

11. Handberg A, Vaag A, Damsbo P, Beck-Nielsen H, Vinten J (1990) Expression of insulin regulatable glucose transporters in skeletal muscle from type 2 (non-insulin-dependent) diabetic patients. Diabetologia 33: 625-627

12. Pedersen O, Bak J, Andersen P et al. (1990) Evidence against altered expression of GLUT1 or GLUT4 in skeletal muscle of patients with obesity or NIDDM. Diabetes 39: $865-870$

13. Eriksson J, Koranyi L, Bourey R et al. (1992) Insulin resistance in type 2 (non-insulin-dependent) diabetic patients and their relatives is not associated with a defect in the expression of the insulin-responsive glucose transporter (GLUT-4) gene in human skeletal muscle. Diabetologia 35: 143-147

14. Garvey WT, Maianau L, Hancock JA, Golichowski AM, Baron A (1992) Gene expression of GLUT4 in skeletal muscle from insulin-resistant patients with obesity, IGT, GDM, and NIDDM. Diabetes 41: 465-475

15. Köbberling J, Tillil H, Lorenz HJ (1985) Genetics of type $2 \mathrm{~A}$ - and type $2 \mathrm{~B}$-diabetes mellitus. Diabetes Res Clin Pract [Suppl 1]: S311 (Abstract)

16. Ferrannini E (1988) The theoretical basis of indirect calorimetry: a review. Metabolism 37: 287-301 
17. Deurenberg P, Weststrate JA, van der Kooy K (1989) Body composition changes assessed by bioelectrical impedance measurements. Am J Clin Nutr 49: 401-403

18. Koranyi L, James D, Mueckler M, Permutt A (1990) Glucose transporter levels in spontaneously obese $(\mathrm{db} / \mathrm{db})$ insulin resistant mice. J Clin Invest 85: 962-967

19. Green F, Edwards Y, Huari HP et al. (1990) Isolation of a cDNA probe for human jejunal brush border hydrolase, sucrose-isomaltase, and assignment of the gene locus to chromosome 3. Gene 57: 101-110

20. James DE, Strube M, Mueckler ME (1989) Molecular cloning and characterization of an insulin-regulatable glucose . transporter. Nature 338: 83-87

21. Fukumoto H, Kyano T, Buse JB et al. (1989) Cloning and characterization of the major insulin responsive glucose transporter expressed in human skeletal muscle and other insulin responsive tissues. J Biol Chem 264: 7776-7779

22. Andersen P, Lund S, Vestergaard H, Junker S, Kahn B, Pedersen O (1993) Expression of the major insulin-regulatable glucose transporter (GLUT4) in skeletal muscle of noninsulin dependent diabetic patients and healthy subjects before and after insulin infusion. J Clin Endocrinol Metab 77: 27-32

23. Nyomba BL, Brautigan DL, Schlender KK, Wang W, Bogardus C, Mott DM (1991) Deficiency in phosphorylase phosphatase activity despite elevated protein phosphatase type-1 catalytic subunit in skeletal muscle from insulin-resistant subjects. J Clin Invest 88: 1540-1545

24. Kellerer M, Muelhöfer A, Zierath J et al. (1993) Expression of IRS- 1 and the $85 \mathrm{kDa}$ subunit of PI-3 kinase in skeletal muscle of patients with non-insulin dependent diabetes mellitus (NIDDM). Exp Clin Endocrinol 101 [Suppl 2]: 300-301

25. Yki-Järvinen $H$, Vuorinen-Markkola $H$, Koranyi $L$ et al. (1992) Defect in insulin action on expression of the muscle/adipose tissue glucose transporter gene in skeletal muscle of type 1 diabetic patients. J Clin Endocrinol Metab 75: 795-799

26. Thompson DB, Degregorio M, Sommercorn J (1992) Insulin resistance alters immediate early gene expression in human skeletal muscle in vivo. Diabetes 41 [Suppl 1]: $89 \mathrm{~A}$ (Abstract)

27. Handberg A, Vaag A, Beck-Nielsen H, Vinten J (1992) Peripheral glucose uptake and skeletal muscle GLUT4 content in man: effect of insulin and free fatty acids. Diabetic Med 9: 605-610

28. Hom FG, Goodner CH (1984) Insulin dose-response characteristics among individual muscle and adipose tissues measured in the rat in vivo with ${ }^{3}(\mathrm{H}) 2$-deoxyglucose. Diabetes 33: 153-159

29. Hirshman MF, Goodyear LJ, Wardzala LW, Horton ED, Horton ES (1990) Identification of an intracellular pool of glucose transporters from basal and insulin-stimulated rat skeletal muscle. J Biol Chem 265:987-991

30. Klip A, Ramlal T, Young DA, Holloszy JO (1987) Insulin-induced translocation of glucose transporters in rat hindlimb muscles. FEBS Lett 224: 224-230

31. Wardzala LJ, Jeanrenaud B (1981) Potential mechanism of insulin action on glucose transport in the isolated rat diaphragm. J Biol Chem 256: 7090-7093

32. Garvey WT, Huecksteadt TP, Matthaei S, Olefsky JM (1988) Role of glucose transporters in cellular insulin resistance of type 2 non-insulin-dependent diabetes mellitus. J Clin Invest 81: $1528-1536$

33. Kahn BB (1992) Facilitative glucose transporters: regulatory mechanisms and dysregulation in diabetes. J Clin Invest 89: 1367-1374 